\title{
Erratum to: Physicians' responses to computerized drug interaction alerts with password overrides
}

\author{
Yasuyuki Nasuhara ${ }^{1 *}$, Ken Sakushima ${ }^{2}$, Akira Endoh $^{3}$, Reona Umeki ${ }^{3}$, Hiromitsu Oki ${ }^{4}$, Takehiro Yamada ${ }^{4}$,
} Ken Iseki ${ }^{4,5}$ and Makoto Ishikawa'

\section{Erratum}

Following publication of our paper in BMC Medical Informatics and Decision Making [1], it was brought to our attention that we had used a slightly modified version of DIAS which had been originally developed by another group [2]. We inadvertently failed to include this paper in the reference list.

On page two, line 21-23 in the left column, this should have been presented as "This study investigated override rates among physicians with awareness of DDIs using DIAS that requires a password override." On page two, line 2-4, in the right column, this should have been presented as "The DIAS that requires a password override at our hospital was originally developed in collaboration between the Department of Hospital Pharmacy and Pharmacology, Asahikawa Medical University and Techno-Forum Co. Ltd., Japan".

As a result, some of figures and tables were similar in both papers, especially figure 1 (in Japanese) is very similar, therefore please disregard it. We sincerely apologize for this oversight.

\footnotetext{
Author details

${ }^{1}$ Division of Hospital Safety Management, Hokkaido University Hospital, Sapporo, Japan. ${ }^{2}$ Department of Regulatory Science, Hokkaido University Graduate School of Medicine, Sapporo, Japan. ${ }^{3}$ Division of Medical Information Planning, Hokkaido University Hospital, Sapporo, Japan. ${ }^{4}$ Department of Pharmacy, Hokkaido University Hospital, Sapporo, Japan. ${ }^{5}$ Laboratory of Clinical Pharmaceutics and Therapeutics, Faculty of Pharmaceutical Sciences, Hokkaido University, Sapporo, Japan.
}

Received: 2 August 2016 Accepted: 2 August 2016

Published online: 10 August 2016
References

1. Nasuhara Y, Sakushima K, Endoh A, Umeki R, Oki H, Yamada T, Iseki K, Ishikawa M. Physicians' responses to computerized drug interaction alerts with password overrides. BMC Med Inform Decis Mak. 2015;15:74.

2. Awaya T, Ohtaki K, Ishihara M, Ono T, Chiba K, Itagaki Y, Yamada T, Suno M, Hayase N, Tasaki Y, Matsubara K. Analysis of Contraindicated Combinations Using a Check System for Drug Interactions, Including those of Injections Pharmacists Should Verify Drug Interactions in Patient Medication Histories. Jpn J Pharm Health Care Sci. 2005;31:425-34.

Submit your next manuscript to BioMed Central and we will help you at every step:

- We accept pre-submission inquiries

- Our selector tool helps you to find the most relevant journal

- We provide round the clock customer support

- Convenient online submission

- Thorough peer review

- Inclusion in PubMed and all major indexing services

- Maximum visibility for your research

Submit your manuscript at www.biomedcentral.com/submit
'Division of Hospital Safety Management, Hokkaido University Hospital,

Sapporo, Japan

Full list of author information is available at the end of the article (c) 2016 The Author(s). Open Access This article is distributed under the terms of the Creative Commons Attribution 4.0 International License (http://creativecommons.org/licenses/by/4.0/), which permits unrestricted use, distribution, and reproduction in any medium, provided you give appropriate credit to the original author(s) and the source, provide a link to the Creative Commons license, and indicate if changes were made. The Creative Commons Public Domain Dedication waiver (http://creativecommons.org/publicdomain/zero/1.0/) applies to the data made available in this article, unless otherwise stated. 